\title{
Implementasi paradigma integrasi-interkoneksi dalam studi manajemen sumber daya manusia
}

\author{
Achmad Muhammad *, Ruspita Rani Pertiwi \\ Universitas Islam Negeri Sunan Kalijaga Yogyakarta. Jalan Marsda Adisucipto, Yogyakarta, 55281, Indonesia \\ achmadmu95@gmail.com \\ * corresponding author
}

\section{ARTICLE INFO}

Keywords

Manajemen SDM

Dosen

UIN Sunan Kalijaga

\begin{abstract}
This research conducted in August-September 2005 under supervision by Lembaga Penelitian UIN Sunan Kalijaga. The main objective was to accelerate the transformation of IAIN to UIN Sunan Kalijaga in the management area. Why management? Because although successful universities are successful primarily because of their teaching and research not because of their management, good management can over time provide the conditions in which teaching and research can flourish, just as, more usually, poor management can undermine teaching and research and precipitate institutional decline. Lecturer as the main actor of teaching and research in universities has a unique characteristic compared to any kind of human resources. Its job descriptions range from serve college student by teaching, serve the scientific world by writing and research, serve institutions by administrative work, to another kind of job descriptions as a social worker who has to serve and develop the community. With those kinds of characteristics, the university has to design special human resource management, we called it Talent Management. A combination of the direct and indirect interview was used to collect primary data. Populations for this research were university and faculty leader or manager who have the authority to design policy about the lecturer. Samples were taken by using proportional consideration: university management consists of the rector and deputy rector II and faculty management consist of the dean of Dakwah, Syari'ah, and Adab and four chiefs of the study program. This research also conducted observations in daily lecturer management practices. Secondary data were compiled from the university's document, homepages, and faculty's document.
\end{abstract}

This is an open access article under the CC-BY-SA license.

\section{PENDAHULUAN}

Kesuksesan sebuah perguruan tinggi diukur dari kesuksesan dalam pengajaran dan penelitiannya, bukan dalam manajemen perguruan tingginya; akan tetapi manajemen yang baik -efektif, efesien, dan berkinerja tinggi- akan dapat menyediakan kondisi yang kondusif dan mendukung bagi aktivitasaktivitas pengajaran dan penelitian, sehingga dapat berjalan lancar dan efektif. Demikian pula sebaliknya, manajemen yang buruk -tidak efektif, tidak efesien, dan berkinerja rendah- akan dapat menghambat, atau bahkan merusak, atau setidaknya mengurangi kualitas penyelenggaraan aktivitas- 
aktivitas pengajaran dan penelitian, dan secara umum dapat menimbulkan kemunduran institusi (Shattock, 2010).

Jika bidang akademik, kemahasiswaan, penelitian dan pengabdian kepada masyarakat merupakan bidang kerja utama (core business) atau tugas pokok dan fungsi (tupoksi) sebuah perguruan tinggi, maka bidang manajemen secara luas memiliki kontribusi yang kritis dan posistif dalam menciptakan lingkungan kondusif yang mendorong dan mempertahankan kesuksesan institusi. Dengan kata lain, kesuksesan institusi dalam menjalankan tupoksi sangat ditentukan oleh kinerja manajemennya.

UIN Sunan Kalijaga sebagai salah satu institusi yang bergerak dalam bidang pendidikan tinggi Islam dapat dijadikan sebagai objek studi yang menarik. Selain ia merupakan Perguruan Tinggi Islam tertua di Indonesia, saat ini ia telah memasuki babak baru dalam perjalanan kelembagaannya, yakni transformasi dari IAIN menjadi UIN, atau dalam istilah manajemen organisasi, UIN sedang sedang mengalami apa yang disebut dengan perubahan dan pengembangan organisasi (organizational change and development). Hal ini menarik untuk dicermati karena proses transformasi UIN Sunan Kalijaga tersebut sudah seharusnya diikuti dengan perubahan kerangka berpikir keilmuan para pengelola lembaga menyangkut pengembangan ilmu, sehingga ia tidak berhenti pada perubahan legal-formaladministratif ataupun sarana fisik, namun sampai pula pada perubahan yang fundamental, yakni bangunan keilmuan yang hendak ditradisikan dengan paradigma integrasi-interkoneksi (Abdullah \& Kartanegara, 2003). Perubahan tersebut tentu juga harus menyentuh pengembangan sistem manajemen yang dianggap menjadi salah satu titik lemah sejak lembaga pendidikan tinggi ini belum bertransformasi dari IAIN Sunan Kalijaga menjadi UIN Sunan Kalijaga (Suryadilaga et al., 2004). Sehingga, manajemen yang diterapkan dalam mengelola SDM misalnya, adalah manajemen yang integrated-interkonected, dimana pengelolaan dan pengembangannya efesien serta bersinergi yang mengimplementasikan manajemen modern dengan didasarkan pada pola pikir strategis sebagai tuntutan yang tak terelakkan.

Dewasa ini paradigma manajemen telah mengalami perubahan (shifting paradigm), tidak saja secara teoritis, tapi juga sebagai bentuk kesadaran baru bahwa faktor kritis yang memungkinkan organisasi bersaing berubah dari bangunan, peralatan, tanah dan modal seperti pada jaman revolusi industri, sekarang menjadi gagasan (idea), kreativitas (creativity), penyelesaian masalah (problem solving) serta penemuan baru (innovation). Implikasinya manusia dalam dunia manajemen organisasi baik yang berorientasi keuntungan (profit oeriented) maupun yang tidak (non-profit oriented), merupakan faktor penentu dan menjadi organ vital, sementara semua komponen selain manusia hanyalah faktor pendukung dan merupakan sumber daya pasif (pasive resources) yang memerlukan aplikasi manusia untuk menjadi sesuatu yang berarti (Fitz-Enz, 2000).

Ditegaskan juga oleh Roger Martin and Mihnea Moldoveanu (Fitz-Enz, 2000) yang menyatakan bahwa dalam era knowledge-based economy, nilai (value) merupakan hasil dari pengetahuan dan informasi. Organisasi tidak dapat menghasilkan keuntungan tanpa ide, keahlian dan talent dari pekerja yang ahli, sehingga organisasi harus bergantung pada manusia. Untuk bertahan pada era ini, organisasi harus mampu dan fokus pada pengelolaan karyawan sebagai sumber daya yang paling berperan.

Dalam proses pengembangan manajemennya, UIN Sunan Kalijaga memfokuskan pada perumusan pola-pola manajemen universitas yang efektif dan efisien, membangun sistem manajemen universitas yang integratif, terukur, dan applicable, guna meningkatkan kualitas pelayanan akademik dan manajemen UIN Sunan Kalijaga secara menyeluruh. Pengembangan pola manajemen tersebut tidak akan berjalan dengan baik apabila tidak didukung oleh sumber daya manusia yang kompeten. Untuk itulah UIN Sunan Kalijaga perlu meninjau kembali implementasi manajemen SDM yang selama ini dianggap menjadi salah satu titik lemah lembaga ini. Sehingga diharapkan manajemen SDM yang diterapkan adalah manajemen SDM yang integrated-interconected, yaitu pengelolaan dan pengembangan SDM yang bersinergi, efesien, dan efektif.

Sumber Daya Manusia dalam suatu perguruan tinggi meliputi staf pimpinan, staf administratif, staf pengajar atau dosen, serta staf pendukung seperti bagian keamanan dan cleaning service. Diantara keempat staf tersebut, dosen memiliki karakteristik bidang kerja yang unik dibandingkan dengan ketiga yang lain, bahkan mungkin dibandingkan bidang kerja manapun. Secara eksplisit bidang kerja dosen telah termaktub dalam tri dharma perguruan tinggi yaitu pengajaran, pengembangan keilmuan, 
serta pengabdian masyarakat. Namun dalam kerangka keorganisasian, dosen juga memiliki hak dan tanggung jawab terhadap lembaga yang menaunginya. Karena keunikannya, maka penelitian ini difokuskan pada pengelolaan terhadap dosen yang selanjutnya disebut dengan manajemen sumber daya dosen.

Penelitian ini bermaksud memberikan sumbangan penelitian berupa suatu desain manajemen sumber daya dosen yang akan dapat mendukung proses transformasi UIN Sunan Kalijaga, khususnya dalam fungsi penyediaan data dan informasi mengenai sumber daya dosen yang diperlukan, sehingga akan dapat dijadikan dasar dalam perencanaan, pengelolaan, pengambilan kebijakan, dan pengembangan sumber daya dosen di UIN Sunan Kalijaga.

Untuk mencapai tujuan tersebut, penelitian ini berusaha untuk menjawab tiga pertanyaan, yaitu sistem manajemen sumber daya dosen seperti apa yang diterapkan di UIN Sunan Kalijaga? Apa kekurangan dan kelebihan sistem manajemen sumber daya dosen yang saat ini diterapkan UIN Sunan Kalijaga? Dan apakah talent management sebagai konsep pengelolaan SDM yang terintegrasi dapat diterapkan sebagai sistem manajemen sumber daya dosen di UIN Sunan Kalijaga?

Di era globalisasi dunia pendidikan menghadapi tiga perubahan besar yaitu perubahan peraturan, perubahan pasar, serta perubahan teknologi yang ketiganya mengacu pada makin ketatnya kompetisi dalam hal peningkatan kualitas (Azahari, 2005). Agar dapat bergerak dalam kompetisi maka perguruan tinggi perlu melakukan repositioning baik dalam pengembangan akademik maupun dalam pengelolaan kelembagaan. Tak bisa disangkal apabila pengembangan akademik tak terlepas dari besarnya anggaran yang harus disediakan. Sehingga muncul wacana untuk mengelola perguruan tinggi dalam bentuk coorporatization sebagai upaya menyediakan fleksibilitas bagi kebutuhan perguruan tinggi untuk berkembang menjadi organisasi yang akuntabel dan otonom. Kendati begitu, perguruan tinggi tidak dapat dikelompokkan secara murni ke dalam profit motive karena tugas pokoknya adalah pendidikan dan pengajaran, walau juga tidak bisa secara murni bersifat non-profit motive bila ingin menjadi otonom. Bagaimanapun ukuran kesuksesan sebuah perguruan tinggi adalah dalam pengajaran dan penelitiannya (Maisyaroh \& Anggraini, 2005).

Bidang Manajemen yang menjadi fokus dalam penelitian ini adalah Manajemen Sumber Daya Manusia yang terdiri dari aktivitas penarikan, seleksi, pengembangan, pemeliharaan, dan penggunaan sumber daya manusia yang dilakukan dalam upaya meningkatkan efektivitas peran sumber daya manusia dalam organisasi. Pengelolaan sumber daya manusia di perguruan tinggi membutuhkan penanganan yang spesifik. Karena sifatnya yang berbeda, pengaturan-pengaturan yang umum diberlakukan pada organisasi tipe lainnya sering menemui jalan buntu bila diberlakukan dalam mengelola sumber daya manusia perguruan tinggi.

Bidang Manajemen Sumber Daya Manusia yang menjadi fokus dalam penelitian ini adalah Manajemen Sumber Daya Dosen. Sumber Daya Dosen memiliki karakteristik bidang kerja yang unik dibandingkan dengan bidang kerja manapun. Secara eksplisit bidang kerja dosen telah termaktub dalam tri daharma perguruan tinggi yaitu pengajaran, pengembangan keilmuan, serta pengabdian masyarakat. Namun dalam kerangka keorganisasian, dosen juga memiliki hak dan tanggung jawab terhadap lembaga yang menaunginya. Karena keunikannya, maka pengelolaan terhadap dosen tidak bisa disamakan dengan sumber daya manusia yang lain.

Ada beberapa model manajemen sumber daya manusia yang diterapkan dalam lingkup organisasi, antara lain model era 1980an yaitu model personalia, model era 1990an yaitu manajemen sumber daya manusia berbasis kompetensi, dan model yang dikembangkan pada era 2000an yaitu Talent Management (Berger \& Berger, 2003). Masing-masing model mempunyai kelebihan, namun model yang lahir berikutnya melengkapi model terdahulu.

\section{METODE}

Penelitian ini menggunakan pendekatan kualitatif karena data yang digali berkaitan dengan sistem manajemen sehingga yang diperlukan adalah data yang kaya dan mendalam dan bukan data yang bisa digeneralisir. Penelitian ini bersifat evaluatif-terapan, yaitu mencoba: (1) Menggali dan menganalisis sistem dan praktek manajemen sumber daya dosen di lingkungan UIN Sunan Kalijaga yang selama 
ini berjalan; (2) Menggali kebutuhan akan sistem manajemen sumber daya dosen yang belum terpenuhi di lingkungan UIN Sunan Kalijaga; (3) Memberi usulan desain sistem manajemen sumber daya dosen yang lebih sesuai dengan UIN Sunan Kalijaga.

Teknik pengumpulan data yang digunakan adalah dokumentasi, pengamatan terlibat (participant observation), dan wawancara. Wawancara sebagai alat penggali primary data dilakukan dengan menggunakan pedoman wawancara yang bersifat semi-structured yang disusun berdasarkan aspekaspek yang akan digunakan untuk menggali praktek manajemen sumber daya dosen di lingkungan UIN Sunan Kalijaga. Dokumentasi sebagai penyedia secondary data berupa data deskriptif dan statistik tentang sumber daya dosen seperti latar belakang pendidikan, golongan, jabatan fungsional sumber daya dosen, status mengenai tugas-tugas sumber daya dosen. Dokumentasi juga memuat sistem manajemen sumber daya dosen walau letaknya dalam dokumen yang tersebar.

Data primer mengenai sumber daya dosen dalam penelitian ini didapat dari wawancara kepada pimpinan yang mempunyai otoritas untuk mengambil kebijakan yang berkaitan dengan sumber daya dosen, yaitu pimpinan perguruan tinggi yang terdiri dari Rektor dan Pembantu Rektor serta pimpinan fakultas meliputi dekan dan ketua jurusan. Data lapangan berupa praktek mananjemen sumber daya dosen di level fakultas dan jurusan dalam penelitian ini diperoleh dengan menggunakan sistem sampling. Metode sampling yang digunakan adalah proportional sampling karena jumlah sample terbatas dan karakteristik yang ingin diungkap mengikuti proporsi tertentu dalam penelitian ini.

Data sekunder mengenai sistem manajemen sumber daya dosen dalam penelitian ini diperoleh dari dokumen-dokumen, khususnya yang berkaitan dengan sumberdaya dosen UIN Sunan Kalijaga seperti buku-buku yang merekam proses transformasi dari IAIN ke UIN Sunan Kalijaga, Buku Pertanggungjawaban Rektor UIN Sunan Kalijaga, dokumen dari bidang kepegawaian, serta dokumen-dokumen pendukung lainnya.

Adapun analisis dilakukan dengan metode trianggulasi yaitu berupaya melakukan cross check data dokumen, pengamatan terlibat, dan hasil wawancara. Peneliti kemudian menganalisis data penelitian yang didapat untuk mendeteksi kebutuhan sistem manajemen sumber daya dosen yang belum terpenuhi di lingkungan UIN Sunan Kalijaga. Untuk kemudian secara kreatif berusaha menjajaki kemungkinan penerapan Talent Management sebagai sistem manajemen sumber daya dosen UIN Sunan Kalijaga

\section{HASIL DAN PEMBAHASAN}

\section{Sistem Manajemen Sumber Daya Dosen UIN Sunan Kalijaga}

Sumber daya dosen adalah seorang yang berdasarkan pendidikan dan keahliannya diangkat oleh penyelenggara perguruan tinggi dengan tugas utama mengajar pada perguruan tinggi yang bersangkutan (Peraturan Pemerintah Republik Indonesia Nomor 60 Tahun 1999 Tentang Pendidikan Tinggi, 1999). Sedangkan tenaga pengajar atau dosen perguruan tinggi di lingkungan Departemen Agama adalah PNS yang diberi tugas, wewenang, dan tanggung jawab oleh pejabat yang berwenang pada Departemen Agama untuk melaksanakan pendidikan dan pengajaran, penelitian, dan pengabdian pada masyarakat atau yang disebut Tri Dharma Perguruan Tinggi.

Kedudukan UIN Sunan Kalijaga berada di bawah wewenang Departemen Agama, maka manajemen sumber daya dosen UIN Sunan Kalijaga dikelola dalam empat level: (a) di level Departemen Agama karena kedudukan sumber daya dosen sebagai PNS; (b) di level universitas karena kedudukan sumber daya dosen sebagai karyawan UIN Sunan Kalijaga; (c) di level fakultas karena kedudukan sumber daya dosen sebagai bagian operasional pendidikan sebuah fakultas; (d) di level jurusan atau program studi kaitannya dengan tugas akademis.

Berikut ini akan dibahas aktivitas manajemen sumber daya dosen UIN Sunan Kalijaga beserta level dan lembaga yang mengelolanya: Sistem rekruitment. Proses rekruitment dimulai dengan tim analisis pekerjaan yang akan membuat perencanaan kebutuhan tenaga kerja. Proses ini dibawah tanggung jawab universitas khususnya bagian kepegawaian namun pelaksanaannya didasarkan pada kebijakan Departemen Agama (terkait jumlah formasi) (Menteri Agama Republik Indonesia, 2000) dan usulan kualifikasi bidang ilmu oleh universitas sesuai kebutuhan fakultas dan program studi 
(Abdullah, 2006). Tim analis pekerjaan setiap tahunnya akan mengecek ke pusat berapa posisi yang kira-kira disetujui Departemen Agama yang nantinya akan terkait dengan anggaran. Setelah itu, tim analisis akan mengecek kebutuhan sumber daya dosen di tiap fakultas dan program studi serta kualifikasi yang dibutuhkan. Setelah terjadi kesesuaian antara kebutuhan fakultas dan program studi dengan jumlah posisi yang disetujui maka tim analis pekerjaan akan membuat pengumuman lowongan sumber daya dosen yang akan disertai dengan tiga level persyaratan dan jumlah kebutuhan.

Tiga level persyaratan meliputi: (1) Syarat-syarat menjadi dosen menurut peraturan pemerintah, yaitu beriman dan bertaqwa kepada Tuhan Yang Maha Esa; berwawasan Pancasila dan Undangundang Dasar 1945; memiliki kualifikasi sebagai tenaga pengajar; mempunyai moral dan integritas yang tinggi; memiliki rasa tanggung jawab yang besar terhadap masa depan bangsa dan negara; (2) Syarat-syarat tersebut masih bersifat umum, kriteria dan kualifikasi serta syarat-syarat administrasi yang lebih rinci diatur oleh masing-masing perguruan tinggi yang bersangkutan, untuk UIN Sunan Kalijaga masih merujuk statuta IAIN Sunan Kalijaga tahun 2002; (3) Syarat diatas masih bersifat administratif, untuk yang berifat khusus kaitannya dengan akademik akan ditambahkan sesuai dengan kebutuhan fakultas dan program studi seperti latar belakang pendidikan S1 dan S2, IP minimal, dll. Ketiga syarat tersebut masih bersifat formal administratif, belum tergambar syarat yang mengungkap keempat kompetensi yang disyaratkan UU Guru dan Dosen.

Proses Seleksi. Setelah blangko lamaran masuk maka langkah pertama proses seleksi adalah seleksi administratif yang dilakukan oleh bagian kepegawaian universitas yang meliputi kelengkapan berkas lamaran dan kesesuaian dengan persyaratan yang diminta. Selanjutnya terhadap yang lolos seleksi administrasi akan diseleksi bersamaan dengan seluruh departemen dalam Tes Seleksi CPNS, dalam tahap ini persiapan soal dan koreksi serta penentuan dilakukan di level pusat. Tes yang tersentralistik mempunyai banyak kelemahan yaitu rentan budaya "titip" serta tes yang kurang mengungkap kompetensi yang dibutuhkan, apalagi bentuk tes hanya tes tertulis padahal kompetensi seorang dosen tidak hanya yang bersifat kognitif, tetapi juga mencakup kemampuan sosial dan personal. Sehingga mulai tahun 2005 seleksi terhadap calon dosen mulai diselenggarakan secara otonom pada masing-masing PTAIN. Di UIN Sunan Kalijaga ditambah dengan tes wawancara, microteaching, dan presentasi makalah yang sesuai bidangnya. Tes ini dimaksudkan mengungkap keempat kompetensi dosen yang disyaratkan UU Guru dan Dosen.

Penempatan (staffing). Setelah dilakukan proses seleksi dan pelamar dinyatakan diterima maka selanjutnya adalah penempatan. Penempatan ini diupayakan sesuai antara latar belakang akademis dengan fakultas dan jurusan dimana dosen akan ditempatkan. Kemudian di level jurusan akan ditempatkan berkaitan dengan SK Mata Kuliah pokok. Dalam pelaksanaannya di UIN Sunan Kalijaga terdapat banyak sumber daya dosen yang penempatannya tidak sesuai, baik itu yang berkaitan dengan minat, background pendidikan, pengalaman, dan kompetensi. Kemudian muncul program regrouping yang akan menganalisis kembali penempatan dosen (Menteri Agama Republik Indonesia, 2000). Sebenarnya hal ini tidak perlu terjadi apabila proses identifikasi dosen dalam proses seleksi dilakukan dengan benar dan penempatan dilakukan berdasarkan hasil identifikasi.

Pelatihan dan pengembangan. Sumber daya dosen sebelum diangkat menjadi tenaga pengajar diharuskan untuk mengikuti pelatihan pra jabatan yang dikelola Bagian Litbang Departemen Agama. Di level universitas pengembangan dilakukan oleh bagian terpisah; pengembangan pedagogis oleh CTSD, pengembangan Bahasa oleh Pusat Bahasa, pengembangan penelitian melalui Lembaga Penelitian, pengembangan pengabdian pada masyarakat ditangani oleh Lembaga Pengabdian Masyarakat. Selain terpisah-pisah, program tersebut juga tidak dilakukan secara merata, siapa yang aktif atau siapa yang ditunjuk pimpinan yang akan dikirim ke program pengembangan. Baru mulai tahun 2006 kegiatan pengembangan dosen baru disatukan menjadi Program Pengembangan Calon Dosen yang berupaya mengembangkan keempat kompetensi yang harus dimiliki oleh dosen. Program ini merupakan suatu terobosan karena menyatukan program pengembangan dalam satu paket terintegrasi.

Penggajian, penghargaan dan sanksi (Reward Management). Dosen UIN Sunan Kalijaga tercatat sebagai PNS Depag sehingga sistem penggajian mengikuti ketentuan Depag. Penggajian diberikan bertingkat sesuai dengan golongan fungsional. Namun selain gaji pokok, juga terdapat insentif terkait 
dengan tugas khusus yang diatur oleh fakultas seperti membuat soal, kelebihan mengajar, koreksi, pembimbingan skripsi, dll. Sementara, pemberian penghargaan dan sanksi, secara normatif, mengacu kepada aturan-aturan kepegawaian yang berlaku, Kode Etik dan Tata Tertib Dosen UIN Sunan Kaljaga (Menteri Agama Republik Indonesia, 2000).

Evaluasi kinerja. Evaluasi kinerja dosen disebut dengan DP3 (Daftar Penilaian Pelaksanaan Pekerjaan). Untuk kinerja dosen yang menilai adalah Pembantu Dekan II dan Dekan. Evaluasi kinerja ini akan berimplikasi pada kenaikan pangkat, apabila skornya menurun maka yang bersangkutan tidak bisa naik pangkat. Namun tindak lanjut dari evaluasi kinerja ini belum terlihat, misalnya yang evaluasi kinerja bagus mendapat reward atau kesempatan pengembangan, yang mengalami masalah dilakukan pendampingan, dll. Sehingga pelaksanaan DP3 selama ini masih bersifat administratif. Evaluasi kinerja terkait kinerja akademis sedang digodog tim Jaminan Mutu, yang disebut dengan Indeks Kinerja Dosen (IKD).

Jenjang karier. Berdasarkan "Pedoman Kenaikan Jabatan Fungsional Dosen IAIN Sunan Kalijaga Yogyakarta", hakekat kenaikan jabatan fungsional dosen merupakan: (a) Kepercayaan atas kemampuan untuk mengemban tugas dan tanggung jawab yang lebih tinggi; (b) Penghargaan atas prestasi akademik yang telah dicapai; (c) Pengakuan atas kemampuan akademik dan keteladanan dalam kehidupan akademik; (d) Harapan dan peluang pengembangan jati diri keilmuan dan profesi demi pencapaian jabatan tertinggi sesuai kemampuan. Selain sebagai jenjang karier, Jabatan Fungsional sebenarnya juga merupakan peta kekuatan sumber daya dosen. Namun pada kenyataannya jabatan fungsional belum mampu memetakan kompetensi dosen karena masih bersifat administratif.

Berdasarkan manajemen sumber daya dosen yang diterapkan UIN Sunan Kalijaga diatas dapat kita ketahui bahwa manajemen sumber daya dosen yang diterapkan di UIN Sunan Kalijaga secara umum masih menggunakan model personalia yang memiliki karakteristik sebagai berikut:

Sistem Manajemen Sumber Daya Dosen masih bersifat administratif sesuai dengan Peraturan Kepegawaian PNS, belum menggambarkan dan memanfaatkan kekuatan sumber daya dosen yang sebenarnya. Hal ini berimplikasi pada dua hal (a) Pertama, UIN Sunan Kalijaga belum mengenal peta kekuatan sumber daya dosen sehingga apabila akan diambil kebijakan yang berkait dengan sumber daya dosen seperti pengiriman utusan, peluang beasiswa, pengiriman keluar negeri, atau ada project keputusan tidak bisa diambil dengan cepat. Prosedur yang selama ini terjadi adalah mengambil personil yang dikenal saja, atau melakukan identifikasi mendadak yang bisa berakibat pada hasil yang kurang memuaskan; (b) Kedua, banyak dosen yang belum teridentifikasi potensi dan kekuatannya sehingga baik pemanfaatan maupun pengembangan terhadap dosen kurang optimal. Hal ini tentu saja merugikan dosen karena tidak bisa menyumbangkan potensi terbaiknya, yang akhirnya juga berimplikasi pada kurang maksimalnya pengembangan UIN Sunan Kalijaga. Pemetaan yang dijalankan selama ini adalah jabatan fungsional, namun kurang bisa menggambarkan kompetensi dosen yang sesungguhnya karena sifatnya administratif.

Dalam pelaksanaannya Manajemen Sumber Daya Dosen bersifat natural, artinya bersifat reaktif belum proaktif. Dari hasil wawancara didapat keterangan bahwa pimpinan dalam melakukan identifikasi dan evaluasi kinerja dosen masih didasarkan pada observasi sehari-hari, bahkan dalam mengambil kebijakan cenderung pada siapa yang ada di dekatnya dan siapa yang mau, bukan didasarkan pada siapa yang mampu, hal ini tentu akan berpengaruh pada hasil kinerja. Dalam pengembangan juga belum didasarkan pada apa yang dibutuhkan oleh sumber daya dosen disesuaikan dengan apa yang dibutuhkan oleh organisasi, tetapi lebih bergantung pada proyek disekeliling, belum dibakukan dalam racangan pengembangan sumber daya dosen. Program Pengembangan Calon Dosen yang dilakukan mulai tahun 2006 adalah merupakan terobosan baru di UIN Sunan Kalijaga, walau dalam pelaksanaannya belum menerapkan assessment pada kebutuhan sumber daya dosen.

Manajemen Sumber Daya Dosen baik program maupun lembaga yang melaksanakan masih terpisah-pisah dan belum terintegrasi sehingga hasil yang diharapkan menjadi kurang maksimal. Aktivitas manajemen sumber daya dosen yang dibahas di poin satu menggambarkan bahwa penerimaan, pengelolaan, pemanfaatan, dan pengembangan sumber daya dosen masih dilakukan dengan program yang terpisah-pisah dan dilakukan oleh lembaga yang menyebar, sehingga kadang terjadi overlap antar program atau pengulangan yang dampaknya adalah inefisiensi. 


\section{Kelebihan dan Kekurangan Manajemen SDD UIN Sunan Kalijaga}

\section{Kelebihan Manajemen Sumber Daya Dosen UIN Sunan Kalijaga}

Manajemen sumber daya dosen yang diterapkan UIN Sunan Kalijaga dengan sistem desentaralisasi yang mengutamakan prinsip pembagian pekerjaan atau tugas sesungguhnya merupakan bagian dari kebutuhan untuk mewujudkan organisasi yang sukses. Dengan pembagian kewenangan mengambil keputusan sesuai posisi atau jabatan pada masing-masing unit, maka setiap masalah pengelolaan dapat diselesaikan pada jenjang yang tepat, tanpa harus melalui birokrasi yang berlebihan. Kondisi seperti ini cukup menguntungkan bagi UIN Sunan Kalijaga karena dapat menjadi bagian dari kecepatan menjalankan program-program kegiatan maupun memberikan respon dalam pengembangan organisasi UIN Sunan Kalijaga.

Sejalan dengan poin tersebut, sistem rekruitmen calon dosen yang didasarkan pada formasi dan klasifikasi yang ditentukan dan diajukan oleh masing-masing jurusan/prodi sebagi unit garda depan yang secara langsung bersentuhan dengan pengelolaan dan pelaksanaan kegiaan akademik sesungguhnya merupakan awal yang tepat untuk mendapatkan SDM (dosen) yang sesuai dengan kebutuhan riil.

Di samping adanya lembaga-lembaga struktural, pembentukan lembaga-lembaga non struktural atau unit-unit yang bertugas menangani proyek atau melaksanakan tugas khusus memberikan banyak ruang bagi dosen untuk berkiprah di UIN Sunan Kalijaga dengan menduduki jabatan-jabatan tertentu pada lembaga-lemabaga atau unit-unit tersebut. Kondisi di atas sekaligus dapat menjadi pintu masuk bagi pemeliharaan dan pengembangan ragam kompetensi dosen.

Dengan format pengelolaan sumber daya dosen yang saat ini diterapkan, memungkinkan UIN Sunan Kalijaga dan para dosen secara timbal balik untuk memberikan dan memperoleh penghasilan tambahan, di luar gaji bulanan sebagai PNS, karena status atau jabatan tertentu dalam struktur organisasi UIN Sunan Kalijaga, maupun lembaga-lembaga atau unit-unit yang dibentuk, atau karena tugas tambahan diluar tugas pokok yang dibebankan. Hal ini secara tidak langsung dapat menjadi stimulan bagi peningkatan kinerja dosen serta motivasi untuk peningkatan dan pengembangan prestasi serta karier dosen.

\section{Kekurangan Manajemen Sumber Daya Dosen UIN Sunan Kalijaga}

Meski sistem rekruitmen dosen sudahkah diawali dengan penentuan formasi dan kualifikasi sesuai dengan kebutuhan jurusan atau prodi, akan tetapi hal ini kerap tidak dilakukan dengan melakukan identifikasi kebutuhan secara cermat. Proses seleksi yang cenderung masih bersifat dominan pada aspek formal-administratif (pada tahap awal) serta bersifat sentralistik dan bukannya oleh jurusan/ prodi yang punya kebutuhan- memungkinkan untuk tidak didapatnya the best people and the right people based on position seperti yang diharapkan.

Sistem desentaralisasi yang mengutamakan prinsip pembagian pekerjaan atau tugas yang tidak dibarengi oleh sistem koordinasi yang solid yang mencerminkan interkoneksitas antar lembaga atau unit menjadikan pengelolaan sumber daya dosen terkesan berjalan sendiri-sendiri, sehingga terjadi penumpukan tugas dan rangkap jabatan yang berlebih serta ketidakmerataan kesempatan peluang pengembangan.

Belum adanya sistem identifikasi sumber daya dosen yang komprehensif serta pemetaannya, semakin mempersulit pimpinan untuk dengan cepat memperoleh informasi yang dibutuhkan dalam penetapan personalia atau kebijakan-kebijakan yang terkait dengan pengelolaan sumber daya dosen.

Pada gilirannya, kondisi ini menjadikan upaya pengembangan sumberdaya dosen kurang dapat dilakukan secara tepat, perencanaan pengembangan belum based on identification. Hal ini jelas berimbas pula pada perolehan kesempatan pengembangan karier maupun kesempatan memperoleh pendapatan tambahan yang kurang merata yang tidak disebabkan oleh faktor merit atau prestasi.

\section{Usulan manajemen sumber daya dosen UIN Sunan Kalijaga yang lebih sesuai}

Dari hasil penelitian didapat kesimpulan bahwa UIN Sunan Kalijaga masih menerapkan model personalia dalam manajemen sumber daya dosen. Model personalia merupakan peletak dasar human resource management, namun dewasa ini telah banyak ditinggalkan karena masih bersifat 
administratif sehingga kurang bisa merespon perkembangan lingkungan organisasi yang sangat pesat. Untuk itu peneliti menawarkan manajemen sumber daya dosen yang lebih bersifat progresif yaitu model talent management. Pertanyaan yang akan muncul adalah mengapa model manajemen SDM yang ditawarkan: talent mangement? Apa keuntungan menerapkan talent management dalam manajemen sumber daya dosen UIN Sunan Kalijaga? Dan desain talent management seperti apa yang sesuai bagi UIN Sunan Kalijaga?

\section{Latar belakang model Talent Management}

Seperti dibahas pada kerangka teori bahwa karakteritik sumber daya dosen harus memiliki empat kompetensi seperti yang diuraikan dalam UU Guru dan Dosen yaitu kompetensi sosial, kompetensi pedagogis, kompetensi profesional, dan kompetensi pribadi, hal tersebut sesuai dengan karakteristik talent karena didalamnya tercakup bakat atau kapasitas "pemikiran strategis yang tajam, jiwa kepemimpinan, keahlian berkomunikasi, kemampuan untuk menarik dan menginspirasi orang lain, instink entrepreneur, keahlian fungsional, dan kemampuan untuk memberikan hasil".

Core bussiness atau tugas pokok UIN Sunan Kalijaga sebagai sebuah universitas adalah penelitian dan pengajaran, sehingga sumber daya dosen adalah ujung tombak bagi UIN Sunan Kalijaga untuk memenangkan kompetisi dunia perguruan tinggi. Manajemen sumber daya dosen yang selama ini dijalankan yang mengacu pada manajemen model personalia tidak lagi efektif untuk menghadapi perubahan lingkungan. Untuk itulah talent management yang menerapkan konsep manajemen talent yang terintegrasi diperlukan.

\section{Konsep Talent management}

Talent Management adalah aktivitas untuk meningkatkan kinerja organisasi dengan cara mengintegrasikan sistem perencanaan, pengelolaan, pengambilan kebijakan, dan pengembangan talent yang didasarkan atau dikontekskan pada peta kekuatan talent yang merupakan hasil dari identifikasi terhadap seluruh talent (Michaels et al., 2001). Dalam penerapannya kapasitas kompetensi dan potensi talent teridentifikasi sehingga talent bisa memberikan kemampuan terbaiknya, organisasi juga memiliki peta kekuatan talent yang integratif sehingga dalam menggunakan, memelihara, dan mengembangkan talent akan menjadi efektif yang akhirnya akan berdampak meningkatnya kinerja organisasi.

Secara rinci talent management terdiri dari tiga aktivitas, yaitu: Pertama, Identifikasi Talent, yaitu mengidentifikasi dan mengassess potensi keseluruhan pegawai, tujuannya agar organisasi tahu kekuatan "pasukan" yang dimiliki. Kedua, Pemetaan Talent, yaitu memetakan keseluruhan potensi pegawai yang sesuai dengan kompetensi yang disyaratkan oleh organisasi. Peta ini menggambarkan seluruh potensi dan kompetensi dari talent sehingga organisasi dapat mengidentifikasi dengan cepat dan tepat siapa yang cocok untuk melakukan tugas tertentu. Ketiga, Pemanfaatan, Pemeliharaan, dan Pengembangan Talent. Aktivitas yang harus dilakukan dalam proses ini adalah: (a) Pemanfaatan talent seperti bila ada project, penempatan, penentuan mata kuliah, pengiriman utusan, beasiswa, dll dilakukan dengan lebih tepat, adil, dan efisien karena berbasis peta potensi talent; (b) Pemeliharaan talent seperti sistem reward yang proporsional dan jenjang karier yang memuaskan yang dilakukan berdasarkan kompetensi talent akan meningkatkan kepuasan kerja yang pada akhirnya akan membuat talent bertahan dan loyal terhadap organisasi, tidak berorientasi proyek keluar; (c) Pengembangan Talent, seperti pelatihan penguasaan untuk kompetensi tertentu, studi lanjut, workshop, dll dilakukan berdasarkan kebutuhan talent sehingga hasilnya akan berdaya guna.

Manfaat penerapan Talent Management bagi UIN Sunan Kalijaga adalah UIN Sunan Kalijaga, yang dalam operasinal aktivitasnya dilakukan oleh para pimpinan atau para pengambil kebijakan di semua level (universitas hingga jurusan/prodi): (a) Memiliki sumber informasi tentang talent beserta posisi jabatan maupun penempatan, mengumpulkan dan mengkomunikasikan informasi rencana tentang sumber daya dosen yang dimiliki; (b) Dapat secara stratejik dan cepat dalam menempatkan sumber daya dosen untuk kebutuhan saat ini dan masa yang akan datang apabila ada kebijakan baru, reorganisasi, konsolidasi, proyek, ataupun merger karena didasarkan pada katalog yang selalu up-todate tentang kualifikasi talent. (c) Akan terbantu dalam menciptakan dan menganalisis skenario succession untuk mencari pemimpin di masa yang akan datang. Siapa yang akan menggantikan orang kunci jika mereka habis masa jabatan, pensiun, sakit, atau meninggal; (d) Dapat memonitor dan 
mengassess kinerja sumber daya dosen secara sistematis; (e) Dapat mengidentifikasi talent yang telah memiliki dan yang sedang mengembangkan kompetensinya; (e) Terakhir, UIN Sunan Kalijaga sebagai sebuah organisasi akan dapat menyeimbangkan tujuan personal sumber daya dosen dengan tujuan organisasi.

\section{Konsep Talent Management UIN Sunan Kalijaga}

Sistem Manajemen Sumber Daya Dosen UIN Sunan Kalijaga apabila dianalisis menggunakan konsep Talent Management maka gambarannya adalah seperti pada Gambar 1.

Dari Gambar 1 bisa terlihat bahwa: Pertama, Ada beberapa poin kunci Talent Management yang belum dilaksanakan, misal identifikasi atau assessment valid terhadap sumber daya dosen yang mencakup keempat kompetensi yang harus dikuasai dosen yaitu kompetensi personal, sosial, profesional, dan pedagogis. Seharusnya data seleksi sudah mencakup ketiganya. Kedua, Belum adanya identifikasi valid menyebabkan belum ada peta sumber daya dosen yang bisa digunakan sebagai dasar pemanfaatan, pemeliharaan, dan pengembangan sumber daya dosen. Ketiga, aktivitas talent management belum terintegrasi, bahkan terkesan tidak ada hubungan diantara ketiganya. Hal ini tentu saja berimplikasi pada kurang efektif dan efisiennya manajemen sumber daya dosen yang pada akhirnya juga memberikan kinerja organisasi yang kurang efektif karena akan terjadi pengulangan dan overlaping kegiatan. Misal setiap ada kegiatan harus dilakukan asessmen ulang yang biasanya akan memakan waktu seperti ketika akan dilakukan pengiriman tim studi banding ke Malaysia dan Singapura dilakukan assessment ulang sampai jam 10 malam yang diantaranya mencakup bahasa, background, aktivitas, dll yang sebenarnya jika sudah ada peta maka tidak perlu dilakukan lagi.

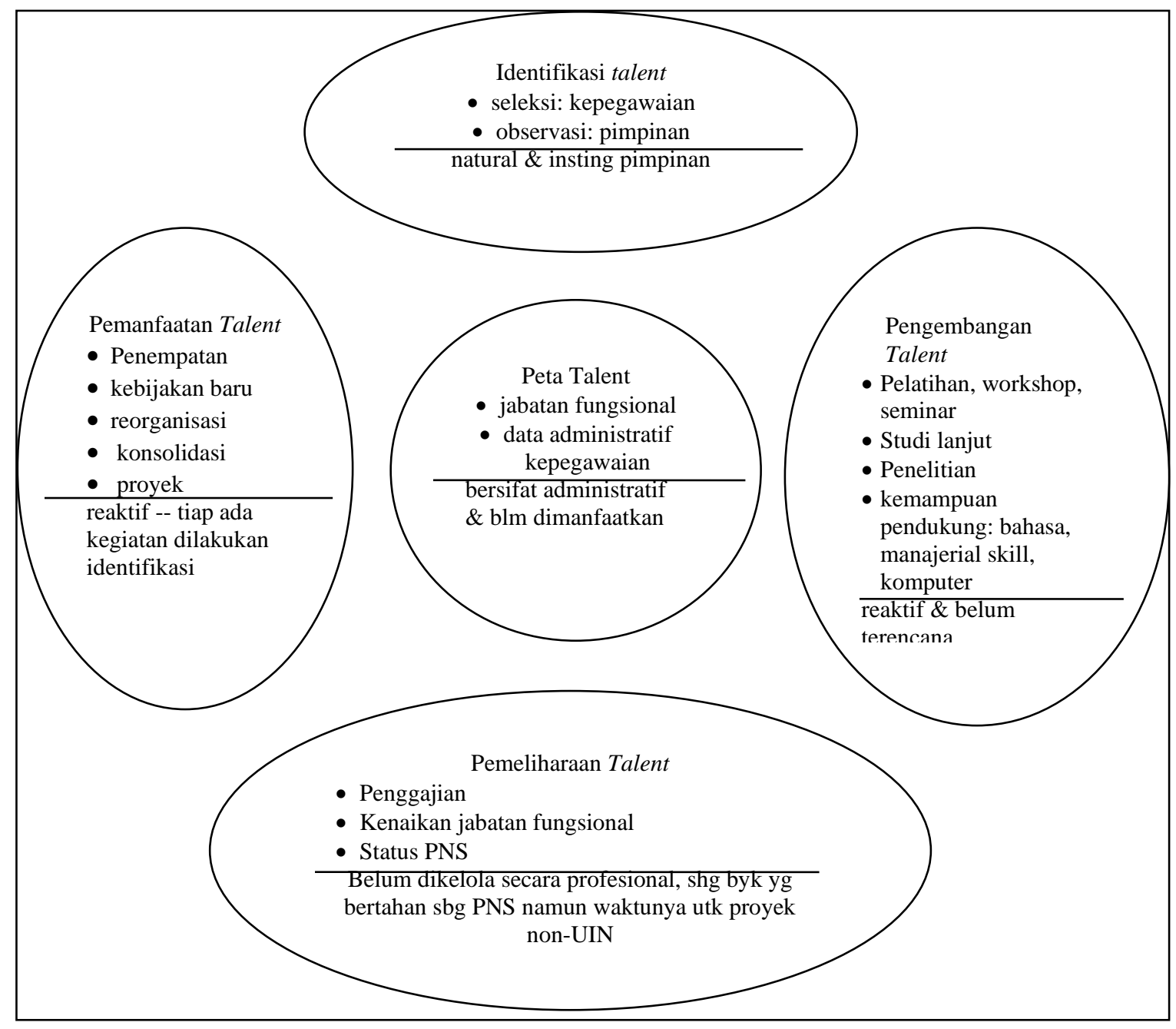

Gambar 1. Sistem Manajemen Sumber Daya Dosen UIN Sunan Kalijaga dianalisis menggunakan Konsep Talent Management 
Berdasarkan praktek manajemen sumber daya dosen, beserta kelebihan dan kekurangannya maka penulis mengajukan desain Talent Management bagi UIN Sunan Kalijaga seperti yang terdapat pada Gambar 2.

Identifikasi Talent. Assessment menyeluruh terhadap sumber daya dosen baik yang bersifat: (a) Hard skill, seperti data pribadi yang berupa background pendidikan dan pengalaman serta aktivitas dan sumbangan terhadap UIN Sunan Kalijaga; (b) Softskill, seperti prestasi akademis, karya ilmiah, karakteristik personal dan sosial, minat, serta kemampuan pendukung seperti penguasaan bahasa, manajerial skill, dan lain-lain.

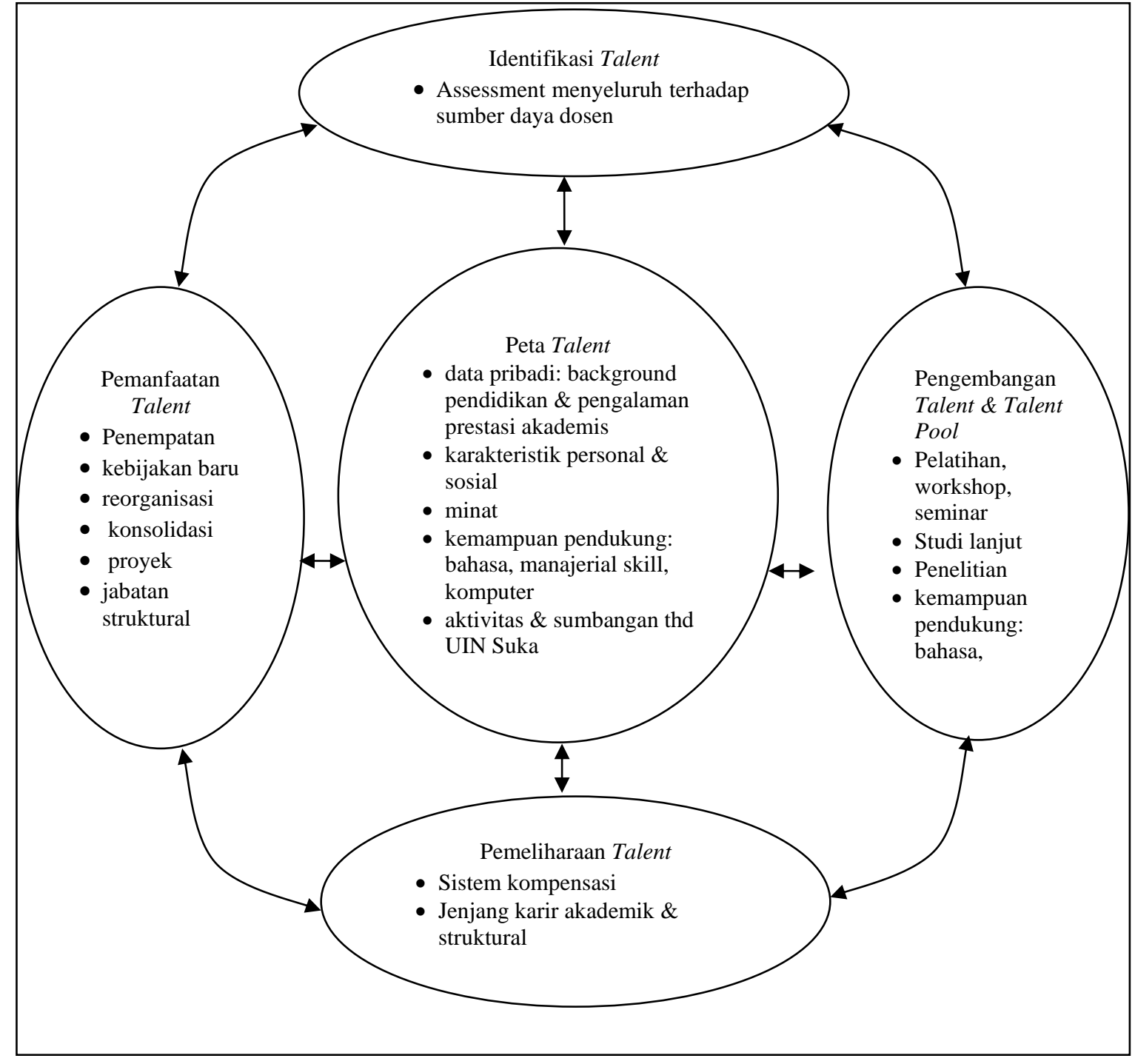

Gambar 2. Desain Talent Management bagi UIN Sunan Kalijaga

Pemanfaatan Talent. Proses ini harus menjamin bagaimana individu dapat memberikan kontribusi kemampuan terbaiknya pada organisasi, untuk itu organisasi juga harus menempatkan orang yang tepat di tempat yang tepat (put the right person on the right job) yaitu dalam aktivitas penempatan akademis, pelaksanaan kebijakan baru, apabila terjadi reorganisasi, apabila diperlukan konsolidasi, apabila ada proyek-proyek pengembangan baru, serta untuk kepentingan pergantian pimpinan (succession planning) jabatan struktural. Untuk bisa menempatkan orang yang tepat ditempat yang tepat maka pengambilan kebijakan harus didasarkan data yang valid tentang talent yang tergambar dalam talent pool. Penempatan orang yang tepat di tempat yang tepat memiliki dua implikasi, yaitu talent termotivasi memberikan kinerja terbaik yang akan berdampak pada meningkatnya kinerja organisasi karena sumbangan efektif dari talent dosen selaku ujung tombak sebuah universitas. 
Pemeliharaan Talent. Pada proses pemanfaatan talent, organisasi mengundang talent untuk menjalankan kewajibannya yaitu berkontribusi kemampuan untuk kepentingan organisasi. Pada pemeliharaan talent, organisasi harus memberikan hak-hak talent agar talent terjaga komitmentnya pada organisasi. Hak-hak talent meliputi sistem kompensasi yang mampu memotivasi serta jenjang karir akademik dan struktural yang jelas dan menarik. Agar fase ini berjalan tepat maka harus didasarkan pada infomasi yang valid tentang talent meliputi kompetensi dan kontribusi terhadap organisasi yang tergambar dalam talent pool.

Pengembangan Talent dan Talent Pool. Ada dua macam pengembangan dalam fase ini, yaitu: (a) Pengembangan Talent meliputi peningkatan kompetensi talent secara individu baik yang bersifat soft skill maupun hard skill, melalui pelatihan, workshop, seminar, studi lanjut, penelitian, dan peningkatan kemampuan pendukung seperti kemampuan bahasa, manajerial skill, serta kemampuan menoperasionalkan komputer dan multimedia. Pengembangan akan efektif apabila didasarkan data valid yang benar-benar memotret kebutuhan talent namun didasarkan pada kepentingan organisasi yang tergambar dalam talent pool. (b) Pengembangan Talent Pool meliputi bagaimana organisasi mengembangkan kekurangan-kekurangan dari kekuatan sumber daya dosen secara berkelompok seperti yang terlihat di peta, misal krisis calon pemimpin akan terlihat dalam talent pool maka diperlukan pelatihan kepemimpinan atau program regenerasi, atau dari peta akan terlihat kekurangan yang menonjol misal penguasaan tekhnologi, bahasa, atau justru kesesuaian background pendidikan. Dari talent pool juga akan terlihat kelebihan dari sumber daya dosen yang dimiliki misal kelebihan pada penguasaan bahasa maka akan dapat dilakukan program tindak lanjut misal berupa pembentukan kelas internasional, dll.

\section{SIMPULAN}

Dari penelitian ini dapat disimpulkan beberapa hal: Manajemen Sumber Daya Dosen di UIN Sunan Kalijaga baik pada level jurusan, fakultas, maupun universitas dalam pelaksanaannya: (a) Sistem Manajemen Sumber Daya Dosen yang diterapkan menggunakan model personalia yang bersifat administratif sesuai dengan Peraturan Kepegawaian PNS, belum tergambar pemanfaatan, pemeliharaan, dan pengembangan sumber daya dosen secara maksimal; (b) Dalam pelaksanaannya Manajemen Sumber Daya Dosen bersifat natural, artinya bersifat reaktif belum proaktif; (c) Manajemen Sumber Daya Dosen baik program maupun lembaga yang melaksanakan belum terintegrasi sehingga hasil yang diharapkan menjadi kurang optimal karena sering terjadi inefesiensi.

Penerapan talent management terhadap sumber daya dosen UIN Sunan Kalijaga sangat memungkinkan untuk dilaksanakan karena: (a) Karakteristik bidang kerja dan kompetensi yang harus dimiliki dosen sangat sesuai dengan konsep talent, sehingga apabila dikelola dengan konsep talent management akan menjadi optimal; (b) Tugas pokok (core business) UIN Sunan Kalijaga adalah penelitian dan pengajaran, dengan dosen sebagai ujung tombak, sehingga penerapan talent management yang menghasilkan peta kekuatan sumber daya dosen dalam bentuk talent pool akan sangat bermanfaat untuk pengambilan kebijakan berkaitan dengan sumber daya dosen dengan lebih cepat, tepat, dan efisien; (c) Sistem terintegrasi berdasar data talent yang akurat dalam talent management akan meningkatkan kinerja sumber daya dosen UIN Sunan Kalijaga yang pada akhirnya berimplikasi pada meningkatnya efektivitas dan kinerja UIN Sunan Kalijaga secara keseluruhan

Berdasarkan simpulan maka tim peneliti merekomendasikan: Pertama, Perlunya dilakukan penelitian lanjutan yang memfokuskan pada identifikasi sumber daya dosen (talent identification) secara komprehensif, mencakup empat kompetensi yang harus dimiliki oleh seorang dosen sesuai dengan Undang-Undang Guru dan Dosen nomor 14 Tahun 2005; untuk selanjutnya dilakukan pemetaan. Kedua, UIN Sunan Kalijaga perlu menyempurnakan kembali sistem koordinasi antar lembaga dan unit terkait manajemen sumber daya dosen sehingga tercipta sistem koordinasi yang solid yang mencerminkan interkoneksitas antar lembaga atau unit. Ketiga, UIN Sunan Kalijaga perlu menciptakan sistem informasi sumber daya dosen, yang terintegrasi dan menyediakan semua data sumber daya dosen secara komprehensif berdasarkan hasil identifikasi talent sehingga memudahkan pimpinan untuk mengaksesnya secara cepat dan tepat dalam setiap pengambilan kebijakan berkenaan dengan penetapan personal dan keputusan-keputusan lain yang terkait 
Secara umum, UIN Sunan Kalijaga perlu melakukan penyempurnaan sistem manajemen sumber daya manusia, khususnya dosen, yang mendukung implementasi paradigma integrasi-nterkoneksi dari proses transformasi menjadi UIN Sunan Kalijaga dengan mengadopsi sistem talent management.

Untuk menjamin sistem manajemen sumber daya dosen dapat berjalan efektif, UIN Sunan Kalijaga perlu membentuk satu unit yang secara khusus menangani manajemen sumber daya dosen.

\section{REFERENSI}

Abdullah, M. A. (2006). Transformasi IAIN Sunan Kalijaga menjadi UIN Sunan Kalijaga. In Laporan pertanggungjawaban Rektor UIN Sunan Kalijaga periode. UIN Sunan Kalijaga.

Abdullah, M. A., \& Kartanegara, M. (2003). Menyatukan kembali ilmu-ilmu agama dan umum: upaya mempertemukan epistemologi Islam dan umum. Sunan Kalijga Press.

Azahari, A. (2005). Isu strategis, peluang, dan tantangan pendidikan tinggi di Indonesia. Seminar Nasional Manajemen Perguruan Tinggi.

Berger, L. A., \& Berger, D. R. (2003). The talent management handbook: Creating organizational excellence by identifying, developing, and promoting your best people. McGraw-Hill.

Fitz-Enz, J. (2000). The ROI of human capital: Measuring the economic value of employee performance. AMACOM Div American Mgmt Assn.

Maisyaroh, A., \& Anggraini, D. (2005). Kompetisi dan strategi dalam membangun perguruan tinggi pada era globalisasi. Jurnal Manajemen.

Menteri Agama Republik Indonesia. (2000). Keputusan Menteri Agama Nomor 438 Tahun 2000 tentang Perubahan Keputusan Menteri Agama 432/1999 tentang petunjuk pelaksanaan seleksi calon Pegawai Negeri Sipil di lingkungan Departemen Agama.

Michaels, E., Handfield-Jones, H., \& Axelrod, B. (2001). The war for talent. Harvard Business Press.

Peraturan Pemerintah Republik Indonesia nomor 60 tahun 1999 tentang pendidikan tinggi, Pub. L. No. 60 (1999).

Shattock, M. (2010). Managing successful universities. McGraw-Hill Education (UK).

Suryadilaga, M. A., Faiz, F., \& Wahyudi, J. (2004). Profil Institut Agama Islam Negeri Sunan Kalijaga Yogyakarta 1951-2004. UIN Suka Press. 